\title{
Association of Porphyromonus gingivalis with Rheumatoid arthritis
}

\author{
Sadeq k. Hachim ${ }^{1}$ MSC, Ahmed A. Abbas ${ }^{2}$ PhD, Mohammed H. Alosami ${ }^{3}$ FICMS (Rheum) \\ ${ }^{1}$ Dept. of Nursing/Babylon Technical Institute, Babylon, Iraq; ${ }^{2}$ Dept. of Microbiology, College of Medicine, Al-Nahrain \\ University, Baghdad, Iraq, ${ }^{3}$ Dept. of Medicine, College of Medicine, University of Baghdad, Baghdad, Iraq
}

\begin{abstract}
Background Rheumatoid arthritis (RA) is chronic systemic inflammatory disease. Porphyromonus gingivalis ( $P$. gingivalis) produce peptidyle arginine enzymes, which lead to citrullination of human protein then lead to formation anticitrullinated peptide antibody (ACPA).

Objective To investigate the role of $P$. gingivalis as environmental factor for RA and association of $P$. gingivalis with development of ACPA.

Methods This study included 31 newly diagnosed RA patients with periodontitis, which included 22 females and 9 men in addition to 30 individual as healthy controls, which included 20 females and 10 men. The exclusion criteria included autoimmune disease (systemic lupus erythematosus, Bachet disease, ankylosing spondylitis, multiple sclerosis), attending Department of Rheumatology in Baghdad Teaching Hospital during period from May 2014 to January 2015. The age range was 20 to 68 years. Disease activity score 28 (DAS28) was calculated for each patient. Five ml of blood sample was taken for detection of ACPA antibody while gingival cervicular fluid was taken by paper point for detection of $P$. gingivalis by polymerase chain reaction (PCR) with specific primer for fimbrial antigen (fimA).

Results The frequency of positive cases with $P$. gingivalis were $13 / 31(41.90 \%)$ while in healthy controls was zero with significant $P$ value $(<0.001)$. The association between anti cyclic citrullinated peptide (ACCP) antibody and frequency of positive cases for $P$. gingivalis was significant $(P<0.041)$. The association of $P$. gingivalis positivity and DAS28 was non-significant $(\mathrm{P}=0.003)$.

Conclusions $P$. gingivalis showed positive association with RA in newly diagnosed patients. The frequency of positive cases for $P$. gingivalis revealed association with positivity of anti-CCP.
\end{abstract}

Key words $\mathrm{RA}, \mathrm{ACCP}, P$. gingivalis

List of abbreviation: $P$. gingivalis = Porphyromonus gingivalis, $\mathrm{RA}=$ Rheumatoid arthritis, $\mathrm{ACPA}=$ anticitrullinated peptide antibody, DAS28 = Disease activity score, $\mathrm{PCR}=$ polymerase chain reaction, ELISA $=$ Enzyme linked immune sorbent assay, USA = United States of America, $\mathrm{bP}=$ base pair, $\mathrm{UV}=$ Ultraviolet

\section{Introduction}

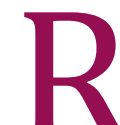

heumatoid arthritis (RA) is a chronic systemic inflammatory disease affecting $0.2-1 \%$ of the population worldwide and is associated with progressive destruction of the joints causes' early mortality and disability. Early diagnosis is challenging because the symptoms of early RA can be non-specific (e.g., malaise, fatigue, weakness, muscle soreness, low down-grade fever, weight loss) and may actually be symptoms of other conditions. Assessment of disease activity and treatment responses is based on measurement of disease activity score28 (DAS28) ${ }^{(1)}$.

Although the causes are indefinite, there is accumulating evidence RA is an autoimmune disease characterized by disease-specific antibodies to citrullinated protein antigens (ACPA). Citrullinated proteins are generated 
by peptidyl arginine deiminases (PADs), enzymes that catalyze the modification of peptidyl-arginine to peptidyl-citrulline ${ }^{(2)}$.

$P$. gingivalis belongs to the phylum bacteroidetes and is a non-motile, gramnegative, rod-shaped, anaerobic, pathogenic bacterium. It establishes in the oral cavity, somewhere it is implicated in confident forms of periodontal disease ${ }^{(3)}$. The Collagen degradation experiential in chronic periodontal disease consequences in part from the collagenase enzymes of this species. It has been revealed in an in vitro study that $P$. gingivalis can attack human gingival fibroblasts and can stay alive in them in the existence of significant concentrations of antibiotics ${ }^{(4)}$.

The bacterium has concerned interest based on epidemiologic relations between RA and periodontitis and the explanation of a novel bacterial peptidyle arginine deaminase (PAD), suggesting a possible etiologic role of $P$. gingivalis in RA during the creation of citrullinated antigens. In RA, an autoimmune response develops in opposition to citrullinated peptides detected as anti-citrullinated peptide antibodies (ACPA). The existence of anti-CCP are $>98 \%$ specific for the diagnosis of RA ${ }^{(5)}$.

The mechanisms to citrullination that guide to RA remain unclear. A polymorphism in the PAD4 gene, which may lead to amplified citrullination has been described in populations. $P$. gingivalis is the only prokaryote recognized to have PAD, an enzyme to facilitate catalyzes the posttranslational modification of arginine residues to citrulline (6).

The objectives of this study was to investigate the role of $P$. gingivalis as environmental factor for RA and association of $P$. gingivalis with development of ACPA

\section{Methods}

This study included 31 newly diagnosed RA patients with 30 persons as healthy controls. The RA patients attended Rheumatology Department in Baghdad Teaching Hospital were examined by rheumatologist during the period from May 2014 to January 2015 and DAS28 was calculated for each patient according to ACR.

\section{Blood samples}

In this study $5 \mathrm{ml}$ of blood were taken from each patients and healthy control by venipuncture, then $3 \mathrm{ml}$ of blood were separated by centrifuge and serum sample was isolated and stored at $\left(-20^{\circ} \mathrm{C}\right)$ until used while $1.6 \mathrm{ml}$ of blood was add to 0.4 of sodium citrate for erythrocyte sedimentation rate (ESR).

\section{ELISA test for anti-CCP:}

The anti-CCP was done by ELISA technique (indirect method) according to instructions manual by Human company/Germany .

\section{DNA-extraction from gingival cervicular fluid} samples

The wizard genomic purification by promega/USA.

Monoplex PCR for detections fimA of $P$. gingivalis was done according to Nakagawa ${ }^{(7)}$.

The primer set was used in detection of $P$. gingivalis as followed:

\begin{tabular}{cccc}
\hline Gene & Primer & $\begin{array}{c}\text { Product } \\
\text { size (bp) }\end{array}$ & Reference \\
\hline Type & CAGCAGAGCCAAAAACAAT & & Nakagawa \\
$\mathbf{1 b}$ & GCTGTCAGATAATTAGCGTC & 250 & ,et al $^{(7)}$ \\
fimA & TGC & & \\
\hline Type & ACAACTATACTTATGACAAT & & Amano,et $^{(8)}$ \\
$\mathbf{1 1}$ & GGAACCCCGCTCCCTGTATT & 200 & al $^{\text {fimA }}$ \\
\hline
\end{tabular}

\section{Statistical analysis}

Prevalence of infection was compared between different variable by Chi-squared test. Significance was attributed to probability $\mathrm{P} \leq$ 0.05 . Computer SPSS and Microsoft were used for determination of probability values. 


\section{Results}

The mean age in newly diagnosed RA patients was 46.3 years versus 43.6 in controls and the $p$ value non-significant as in table (1).

Table 1. Mean age in newly diagnosed rheumatoid arthritis patients

\begin{tabular}{ccc}
\hline Age (yr) & Control & $\begin{array}{c}\text { Newly diagnosis } \\
\text { RA patients }\end{array}$ \\
\hline $\begin{array}{c}\text { Mean } \\
\text { Standard }\end{array}$ & 43.6 & 46.03 \\
Deviation & 11.28 & 12.35 \\
Median & 43 & 50 \\
Minimum & 18 & 20 \\
Maximum & 65 & 67 \\
\hline P value & \multicolumn{3}{|c}{} \\
\hline
\end{tabular}

Table (2) showed distribution of severity state (high, moderate, mild, remission) in newly diagnosed RA patients.

Table 2. The DAS28 score in treated and newly diagnosed RA patients

\begin{tabular}{|c|c|c|}
\hline & & $\begin{array}{c}\text { Newly diagnosis } \\
\text { RA patients }\end{array}$ \\
\hline \multirow{2}{*}{ Remission } & Count & 3 \\
\hline & $\%$ & $9.7 \%$ \\
\hline \multirow{2}{*}{ Mild } & Count & 6 \\
\hline & $\%$ & $19.4 \%$ \\
\hline \multirow{2}{*}{ Moderate } & Count & 9 \\
\hline & $\%$ & $29.0 \%$ \\
\hline \multirow{2}{*}{ High } & Count & 13 \\
\hline & $\%$ & $34.5 \%$ \\
\hline \multirow{2}{*}{ Total } & Count & 29 \\
\hline & $\%$ & $100 \%$ \\
\hline P value & & 0.665 \\
\hline
\end{tabular}

The frequency of positive cases for anti-CCP were 23 out of 31 RA patients while in controls was zero with significant association $(P<0.001)$ as in table (3).
Positivity of $P$. gingivalis in newly diagnosed RA patients was 13 (41.9\%) out of 31 , while negative in all cases of control with significant difference ( $P$ value $<0.001)$ as in table $(4)$ and (Figure 1, 2).

Table 3. Serum anti-CCP positivity in newly diagnosed RA patients versus controls

\begin{tabular}{cccc}
\hline & & Control & $\begin{array}{c}\text { Newly } \\
\text { diagnosis } \\
\text { RA patients }\end{array}$ \\
\hline Positive & Count & 0 & 23 \\
& $\%$ & $0.0 \%$ & $74.2 \%$ \\
Negative & Count & 30 & 8 \\
& $\%$ & $100 \%$ & $25.8 \%$ \\
Total & Count & 30 & 31 \\
\hline P value & $\%$ & $100 \%$ & $100 \%$ \\
\hline
\end{tabular}

Table 4. The frequency of positive cases with $P$. gingival in newly diagnosed patients and healthy controls

\begin{tabular}{cccc}
\hline & & Control & $\begin{array}{c}\text { Newly } \\
\text { diagnosis } \\
\text { RA patients }\end{array}$ \\
\hline Positive & Count & 0 & 13 \\
& $\%$ & $0.0 \%$ & $41.9 \%$ \\
Negative & Count & 30 & 18 \\
& $\%$ & $100 \%$ & $58.1 \%$ \\
\hline Total & Count & 30 & 31 \\
\hline P value & $\%$ & $100 \%$ & $100 \%$ \\
\hline
\end{tabular}

Table (5) shows significant association between positive cases of $P$. gingivalis and anti-CCP positivity with $P$ value $<0.05$. 
Current study revealed no association between $P$. gingivalis infection and DAS score with $\mathrm{P}$ value $=0.003$ as in table (6).

Table 5. Relationship between $P$. gingivalis positivity and anti-CCP of newly diagnosed RA patients

\begin{tabular}{ccc}
\hline $\begin{array}{c}\text { P. } \\
\text { gingivalis }\end{array}$ & No. & $\begin{array}{c}\text { Mean } \pm \text { SD } \\
\text { of CCP }\end{array}$ \\
\hline Positive & 13 & $168.46 \pm 34.33$ \\
Negative & 18 & $78.94 \pm 25.53$ \\
LSD value & ---- & 85.603 \\
P value & ---- & 0.0410 \\
\hline
\end{tabular}

$*$ Significant $(\mathrm{P}<0.05)$
Table 6. The frequency of positive cases with $P$. gingivalis in newly diagnosed patients

\begin{tabular}{ccccc}
\hline DAS28 & \multicolumn{4}{c}{ P. gingivalis } \\
& Negative & Positive \\
& No. & $\%$ & No. & $\%$ \\
\hline Remission & 1 & 2.8 & 2 & 7.7 \\
Mild & 1 & 2.8 & 5 & 19.2 \\
Moderate & 6 & 16.7 & 3 & 11.5 \\
High & 10 & 27.8 & 3 & 11.5 \\
\hline Total & 18 & 51.1 & 13 & 49.9 \\
\hline P value & \multicolumn{4}{c}{0.003} \\
\hline
\end{tabular}

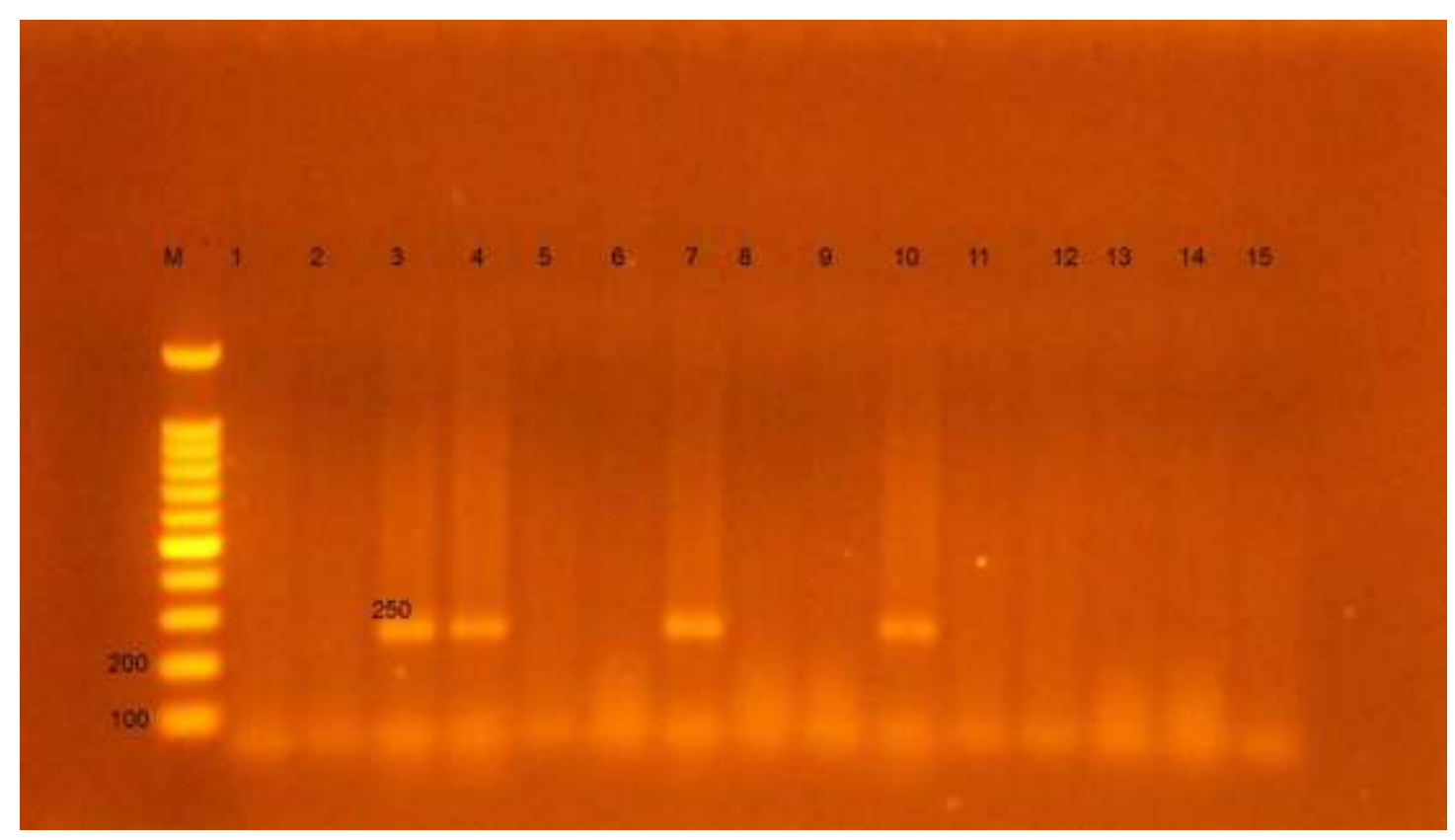

Fig. 1. Gel electrophoresis for PCR product of $P$. gingivalis type $\mathrm{Ib}$ fim visualized under UV light.M:1000 bp marker lane $(3,4,7,10)$ were positive for type $\mathrm{lb}$. The size of product was $250 \mathrm{bp}$ (time $\mathbf{9 0}$ mint., $\mathbf{5 0}$ volt)

\section{Discussion}

Porphyromonus gingivalis genome detection was done for newly diagnosed RA cases by PCR to detect FimA (fimbrillin antigen), which consider highly specific for $P$. gingivalis; two type of FimA were used (FimA type 1b, FimA type II) to increase specificity and to diagnosis bacteria from gingival cervcular fluid ${ }^{(9)}$. The positive cases were $(41.90 \%)$ of thirty one newly diagnosed RA patients. Relationship of $P$. gingivalis infection with RA could be illustrated by mechanisms of secreted enzyme peptidyle arginine deaminase, which lead to citrullination and permanent post-translation of arginine to citrulline as a consequence for this event will lead to accumulation of citrullinated peptide with development of anti citrullinated peptide antibody, which concerned in RA and useful diagnostic marker for RA. This agree with Hitchon, et al who proposed that citrullination 
of human protein by bacterial enzymes will lead to production of ACPA which used as good diagnostic markers for RA ${ }^{(10)}$.

There were $41.90 \%$ of newly diagnosed RA patients have infection with $P$. gingivalis infection as well as there is high titer of ACPA in newly diagnosed RA patients, this finding reflect the role of $P$. gingivalis as one of environmental factor for RA and stimulation for ACPA formations. $P$. gingivalis infection showed a significant association with DAS, so the bacteria may responsible on initiating autoimmune process, which end with development of RA as well as infection with bacteria may exacerbate RA. This finding agree with Al-katma, et al (2007), who hypothesized that control of periodontal infections and gingival inflammation by scaling roots planning and plaque control in subjects with periodontal disease reduce the severity of RA ${ }^{(11)}$. However, this result disagree with Lugli et al (2014), who proposed that $P$. gingivalis infection, which causes periodontitis was associated with development of RA not with severity because severity of disease depend on autoimmune process not on infection with $P$. gingivalis ${ }^{(12)}$.

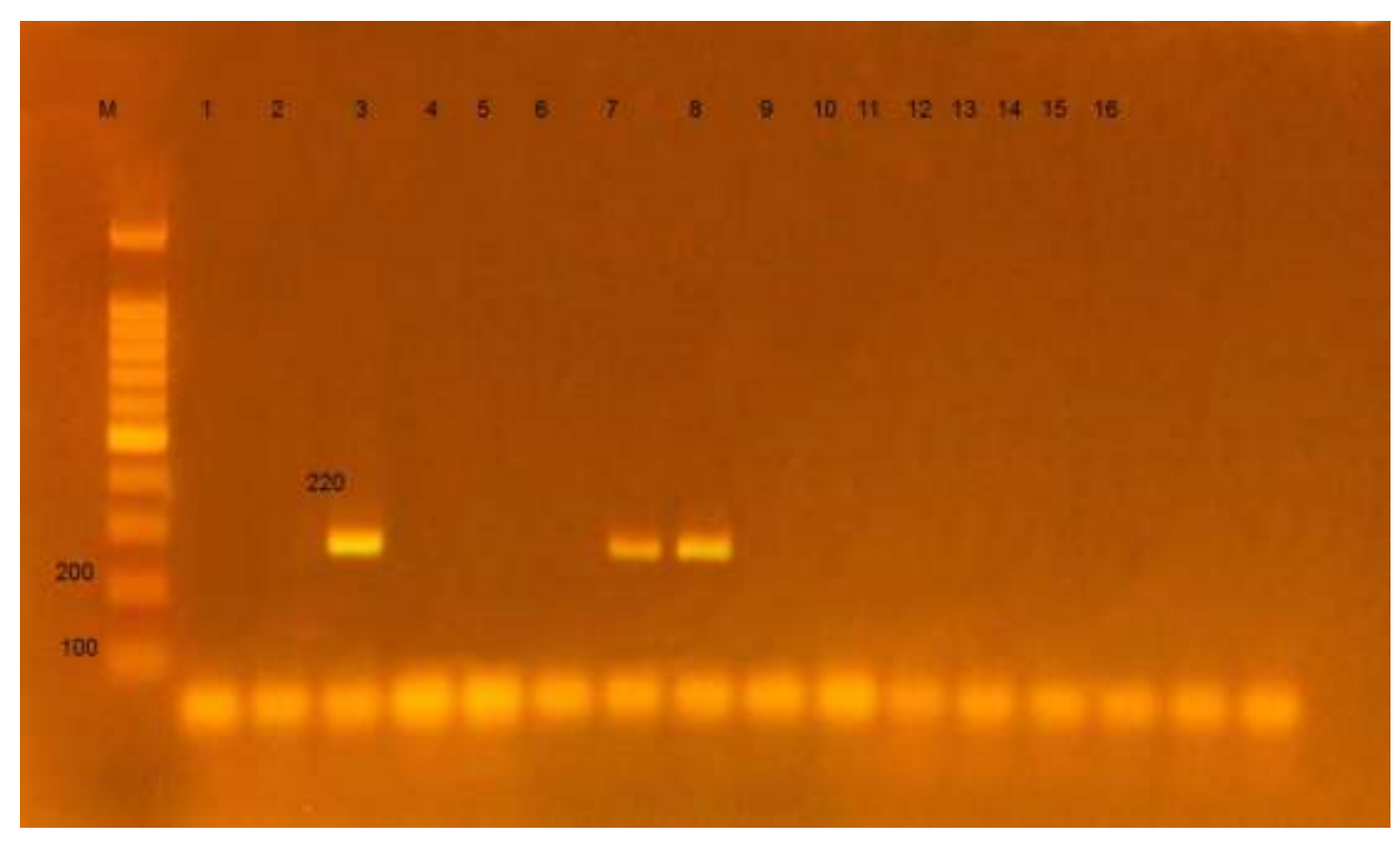

Fig. 2. Gel electrophoresis for PCR product of $P$. gingivalis type II fim visualized under UV light.M:1000bp marker lane $(3,7,8)$ were positive for type II fim . the size of product 220 bp (time 90 mint., 50 volt) 
Molecular mimicry between citrullination of protein by bacterial enzyme and human protein may be responsible for production of ACPA ${ }^{(13)}$. ACPA in newly diagnosed RA patients was high in association with positivity of $P$. gingivalis infections this proved role of bacteria as environmental factor for RA when individual infected with these bacteria will have periodontal disease then there is high tendency to affect with RA ${ }^{(14)}$.

This study concluded that $P$. gingivalis may be consider as risk factor for RA and showed correlation with positivity of anti-CCP.

\section{Acknowledgements}

The authors sincerely thank the patients for participating in this work.

\section{Author contribution}

Sadeq: Data collection and drafting of the article. Ahmed: Design of the work, data interpretation, drafting and critical revision of the article. Mohammed: samples collection.

\section{Conflict of interest}

The authors declare no conflict of interest.

\section{Funding}

No funding was for this research.

\section{References}

1. Scher JU, Abramson SB. Periodontal diseases, Porphyromonas gingivalis and rheumatoid arthritis: What triggers autoimmunity and clinical diseases? Arthritis Res Ther. 2013; 15(5): 122. DOI: 10.1186/ar4360

2. McNally E, Keogh C, Galvin R, et al. Diagnostic accuracy of a clinical prediction rule (CPR) for identifying patients with recent-onset undifferentiated arthritis who are at a high risk of developing rheumatoid arthritis. Sem Arth Rheumat. 2014; 43(4): 498-507.

3. Naito $M$, Hirakawa $H$, Yamashita, et al. Determination of the genome sequence of Porphyromonas gingivalis strain ATCC 33277 and genomic comparison with strain W83 revealed extensive genome rearrangement in $P$. gingivalis. DNA Res. 2008; 15(4): 215-25.

4. Irshad M, Van der Reijden WA, Crielaard W, et al. In vitro invasion and survival of Porphyromonus gingivalis in gingival fibroblast, role of capsule. Arch Immunol Ther Exp. 2012; 60(6): 469-76.
5. Law SC, Street $\mathrm{S}, \mathrm{Yu} \mathrm{CH}$, et al. T-cell autoreactivity to citrullinated autoantigenic peptides in rheumatoid arthritis patients carrying HLA-DRB1 shared epitope alleles. Arthritis Res. 2012; 14(3): R118. doi: 10.1186/ar3848.

6. Arvikar SL, Collier DS, Fisher MC, et al. Clinical correlations with porphyromonas gingivalis antibody responses in patients with early rheumatoid arthritis. Arthritis Res Ther. 2013; 15: R109.

7. Nakagawa I, Amano A, Ohara-Nemoto Y, et al. Kimura variant of fimA gene of porphyromonus gingivalis and its distribution in adults and disabled populations with periodontitis. J Periodontal Res. 2002; 37: 425-32.

8. Amano A, Nakagawa I, Kataoka K, et al. Distribution of porphyromonus gongivalis strains with fimA genotype in peridonitis patients. J Clin Microbiol. 1999; 37: 142630.

9. Koehler A, Karch H, Beikler T, et al. Multilocus sequence analysis of porphyromonus gingivalis indicates frequent recombination microbiology. Microbiology. 2003; 149: 407-15.

10. Hitchon CA, Chandad F, Ferucci ED, et al. Antibodies to Porphyromonus gingivalis are associated with anticitrullinated protein antibodies in patients with rheumagtoid arthritis and their relatives. J Rheumatol. 2010; 37: 1105-12.

11. Al-Katma MK, Bissada NF, Bordeaux JM, et al. Control of periodontal infections reduces the severity of active rheumatoid arthritis. J Clin Rheumatol. 2007; 13(3): 134-7.

12. Quirke AM, Lugli EB, Wegner $N$, et al. Heightened immune response to autocitrullinated Porphyromonus gingivalis peptidylarginine deimminase: a potential mechanism for breaching immunologic tolerance in rheumatoid arthritis. Ann Rheum Dis. 2014; 73: 263-9.

13. Harvey GP, Fitzsimmons TR, Dhamarpatni AA, et al. Expression of peptidyl arginine deiminase 2 and 4,citrullinated proteins and anti-citrullinated protein antibodies in human gingiva. J Periodontal Res. 2013; 48: 252-61.

14. Niewold TB, Harrison MJ, Paget SA. Anti-CCP antibody testing as diagnostic and prognostic tool in rheumatoid arthritis. QJM. 2007; 100(4): 193-201.

Correspondence to Sadeq k. Hachim

E-mail: sadeq.kadhim2016@yahoo.com Received $30^{\text {th }}$ Mar. 2016: Accepted $13^{\text {th }}$ Jul. 2016 